\title{
The Relationship Between Livestock Income and Food Security: A Case Study of Jhal Magsi, Balochistan, Pakistan
}

\author{
Khalid Khan \\ Associate Professor of Economics, Lasbela University of Agriculture Water and Marine Sciences (LUAWMS), \\ Uthal, Balochistan \\ Mujeeb-ur-Rahman Abro \\ Assistant Professor, Department of Media and Communication Studies, Shah Abdul Latif University, Khairpur \\ Mir's \\ Guo Xiangyu \\ Department of Agricultural and Forest Economic Management, Northeast Agricultural University, Harbin, \\ Heilongjiang 150030 \\ Po Bunnika \\ Department of Agricultural and Forest Economic Management, Northeast Agricultural University, Harbin, \\ Heilongjiang 150030
}

\begin{abstract}
The study gives an overview of the possible contribution of livestock to food security in Jhal Magsi, Balochistan. Since livestock is a key factor in boosting rural households' income, livelihood and improving their living conditions. Therefore, the study used primary data collected via well-organized questionnaire from 200 households from various areas of Jhal Masgsi. The result of the study shows that small farmers extensively depend on livestock as key source of income generation. In addition, livestock plays an important role in satisfying the basic needs of food requirements of many families in Jhal Magsi like other rural areas. Henceforth, livestock provides fundamental protection against food insecurity. Furthermore, livestock cultivation also provides income opportunities to households to invest on family: education, health and housing ultimately improve the living standard of family. However, orthodox and dogmatic methods, lack of knowledge and lack of veterinary clinic facilities lead to affect the productivity of the animals. Therefore, the government is called on to provide farmers with the necessary facilities of financing and veterinary services to improve their income, lives and food availability. In addition, livestock may be one of the potential solutions to poverty and malnutrition in backward areas such as Jahal Magsi.
\end{abstract}

Keywords: Livestock, Food Security, Livelihoods, Jahal Magsi and Balochistan

DOI: $10.7176 / \mathrm{DCS} / 9-2-05$

\section{Introduction}

Agriculture is the foundation of Pakistan economy. Since Pakistan is one of the most vulnerable country to climate change, so it will definitely upsurge production costs and diminish net profits, henceforth this will affect people's livelihoods. Therefore farmers should not "put all eggs in one basket" and besides agriculture or horticultural activities should also invest in livestock farming to support uncertain financial losses or generate alternative food and income security in case of calamity or weather shocks. Though, under certain circumstances, livestock is a major source of support to farmers' basic necessities, food and income. At present majority of the people living in developing countries are depending on livestock one way or another for their survival (Rigg et al., 2009). It is well known from the literature of livestock that animal breeding has played an important role in reducing poverty, food insecurity, inadequate nutrition, malnutrition and source of income generation in rural households. In the same way, Khalid (2018) also investigated that livestock accomplish the household demand for increased incomes, wealth, fertilizers, energy and other basic necessities. According to Freeman et al. (2008), in South Africa livestock return is a significant component of family income. His research shows that more than half of the respondents have switched to commercial farming from domestic animals due to its high returns. Ali (2007) quantifies that livestock provides income to 675 million farmers globally as they rely exclusively on livestock breeding. Furthermore, livestock breeding helps low-income rural households in expending their income and living resources. Khalil (2007) mentioned that cattle farming cater the demand for milk and meat of households. Nevertheless, milk and meat are equally important and indispensible nutritious source for humans.

In the modern world, food security is one of the biggest challenges for emerging countries like Pakistan. Nonetheless, livestock products play a key role in sustenance and protein requirements. However, on average the daily animal protein requirement is 27 grams for a healthy human being, whereas Pakistan has only 14.25 grams of capacity per head, which shows that the protein deficiency is $48.7 \%$, nevertheless, this deficiency can be 
bridged through boosting livestock sector. (Miller, 2001) pointed out that demand for livestock products in developing countries will be doubled over the next 20 years, as a result of this it will further lead to accelerate agricultural activities. Therefore, farmers must make decisions about cutting-edge technology and innovation to increase livestock and thus can combat food shortages. In this context, the current research attempts to investigate the contribution of livestock to household's food security and that how it can uplift the standard of living of rural families in Jahal Magsi, Balochistan via livestock. Rest of the study has been categorized as follows: the upcoming three section provided details about: methodology, results and discussion and conclusion respectively.

\section{Methodology}

The study was carried out in the Jahal Magsi region of Balochistan. Jahal Masgi is of the finest area for livestock population in Balochistan, and well known for animals breeding. Hereafter, sample of total of two hundred farmers were randomly selected from the district. Henceforward, the data has been tested for statistical significance by using various statistical tools like: simple frequency distribution, percentage, mean and standard deviation. The results in Table 01 show that $60 \%$ of breeders are between 35 and 60 years old. However, 30\% of respondents are under the age of 35, indicating a high percentage of youth in Jal Magsi are associated to livestock. Moreover, about 58\% of farmers out of selected sample were uneducated, whereas 25\%, $15 \%$ and $02 \%$ of the farmers have primary, intermediate and metric level education.

Table 01. DEMOGRAPHICS CHARACTERS OF THE HOUSEHOLDS

\begin{tabular}{|c|c|c|c|c|c|}
\hline \multicolumn{2}{|c|}{ LITERACY RATE } & \multicolumn{2}{|c|}{ LAND HOLDING (ACRES) } & \multicolumn{2}{|l|}{ TENANCY } \\
\hline Up to Primary & $47 \%$ & Up to 6 & $55 \%$ & Tenancy Status Owner & $45 \%$ \\
\hline Middle & $38 \%$ & $06-10$ & $25 \%$ & Owner-cum-tenant & $50 \%$ \\
\hline Metric and above & $15 \%$ & Above 10 acres of land & $20 \%$ & Tenant & $05 \%$ \\
\hline TOTAL & $100 \%$ & TOTAL & $100 \%$ & TOTAL & $100 \%$ \\
\hline \multicolumn{2}{|c|}{ MARITAL STATUS } & \multicolumn{2}{|l|}{ AGE } & & \\
\hline Unmarried & $41 \%$ & Age (years) up to 35 & $40 \%$ & & \\
\hline \multirow[t]{2}{*}{ Married } & \multirow[t]{2}{*}{$59 \%$} & $36-50$ & $35 \%$ & & \\
\hline & & Above 50 & $25 \%$ & & \\
\hline TOTAL & $100 \%$ & TOTAL & $100 \%$ & TOTAL & $100 \%$ \\
\hline
\end{tabular}

Note: Authors own estimations from Primary data.

The majority of farmers have small landholding, as a large number of farmers i.e. (75\%) have less than 8 hectares of farms. Moreover, the vast majority $(65 \%)$ of cattle owners used their land to cultivate for different crops according to their desires.

Table 2. LIVESTOCK FARMERS INCOME SOURCES

\begin{tabular}{|c|c|c|c|c|c|}
\hline \multicolumn{6}{|c|}{ LIVESTOCK WITH OTHER OCCUPATIONS } \\
\hline $\begin{array}{l}\text { Livestock } \\
\text { Husbandry }\end{array}$ & $\begin{array}{l}\text { Livestock with } \\
\text { Minor } \\
\text { Crops/Orchard } \\
\text { farming }\end{array}$ & $\begin{array}{l}\text { Livestock with } \\
\text { Minor } \\
\text { Crops/Orchard } \\
\text { farming }\end{array}$ & $\begin{array}{l}\text { Livestock } \\
\text { with } \\
\text { services }\end{array}$ & $\begin{array}{c}\text { Livestock with } \\
\text { Minor } \\
\text { Crops/orchard and } \\
\text { services }\end{array}$ & Total \\
\hline $40 \%$ & $20 \%$ & $18 \%$ & $12 \%$ & $10 \%$ & $100 \%$ \\
\hline \multicolumn{6}{|c|}{ PURPOSE OF LIVESTOCK } \\
\hline $\begin{array}{l}\text { Livestock for } \\
\text { Domestic } \\
\text { Purpose }\end{array}$ & \multicolumn{2}{|c|}{ Livestock for Commercial Purpose } & \multicolumn{2}{|c|}{$\begin{array}{l}\text { Livestock for both Domestic \& } \\
\text { commercial purpose }\end{array}$} & Total \\
\hline $45 \%$ & \multicolumn{2}{|c|}{$30 \%$} & \multicolumn{2}{|c|}{$25 \%$} & $100 \%$ \\
\hline
\end{tabular}

Note: Authors personal estimation from Primary data.

Similarly, Table 02 shows that approximately $40 \%$ of the farmers have comprehended that livestock is their only means of living, even though $60 \%$ of farmers say that they have livestock adjunct to other activities like orchards, governments' job and other commercial activities. The main objectives of livestock farming in rural areas are to generate income and means of subsistence. Likewise, our findings go in the same direction as pointed by (Khushk and Hisbani, 2004) since they found that parallel farming with livestock is the most realistic source of income for a rural family.

Table 03 shows the outcome of monthly household income, indicating that the average current income of small farmers is almost below than Rs. 10,000, on the other hand comparatively advanced farmers earn from Rs 10,000 to 17,000 per month. A good number of the revenue comes from the sale of milk and animals for various purposes. For example, the data shows that (52\%) the farmers earn a monthly income of 10,000 to 17,000 rupees (Table 3), though $28 \%$ of farmers receive below Rs 10,000 , whereas $20 \%$ of turnover exceeds Rs. 17,000 because they have advanced agriculture and farming technologies. 
Table 3. Livestock Farmers Monthly Income

\begin{tabular}{|c|c|}
\hline INCOME & Percentages \\
\hline Upto 10,000 & $28 \%$ \\
\hline 10,000 to 15,000 & $52 \%$ \\
\hline 15,000 to 20,000 & $12 \%$ \\
\hline 20,000 and above & $08 \%$ \\
\hline Total & $100 \%$ \\
\hline Livestock as a Foundation for food security & \\
\hline DEPENDENCY OF LSI & Percentages \\
\hline Below $20 \%$ & $05 \%$ \\
\hline Below $40 \%$ & $10 \%$ \\
\hline Below $60 \%$ & $20 \%$ \\
\hline Below $80 \%$ & $50 \%$ \\
\hline Below $100 \%$ & $20 \%$ \\
\hline Total & $100 \%$ \\
\hline
\end{tabular}

Note: Authors own calculation, percentage are in parentheses.

The average value 3.12 clearly shows that the role of livestock in income generation is vital and more important. Though, $03 \%$ of households consider that livestock does not play a vital role in satisfying households wants. In contrast, $80 \%$ of farmers identify the livestock is the principal contributor to meet the needs of their family. The data also showed that breeding animals has been a source of family empowerment, especially in rural areas.

The results in Tables 05 and 06 shows that animal production is appropriate source of households food, income, skills, education, family health and livestock. In addition, it should be noted that livestock breeding is not only important for the strengthening rural socio-economic setup, but also plays a key role in the provision of rural livelihood. We know that women in rural areas are less empowered and livestock helps them in empowerment. In addition, livestock ropes households' health and education as livestock usually make up the largest share of household income in rural areas. However, the market facilities are insufficient and the lack of information and poor infrastructure hinders livestock production to some extent.

Table 04. Effect of Livestock Income on Education, Livestock Health and Livelihoods

\begin{tabular}{|c|c|c|c|c|c|}
\hline SEA & SD & Disagree & Neutral & Agree & SA \\
\hline Education of the children & $06 \%$ & $08 \%$ & $10 \%$ & $56 \%$ & $40 \%$ \\
\hline Livestock health or Standard & $17 \%$ & $10 \%$ & $11 \%$ & $37 \%$ & $25 \%$ \\
\hline Food safety & $01 \%$ & $03 \%$ & $10 \%$ & $46 \%$ & $40 \%$ \\
\hline \multicolumn{6}{|c|}{ EFFECT OF LIVESTOCK INCOME EMPOWERMENT, FAMILY INCOME AND HEALTH } \\
\hline Empowerment & $11 \%$ & $08 \%$ & $08 \%$ & $45 \%$ & $49 \%$ \\
\hline Family income & $07 \%$ & $06 \%$ & $10 \%$ & $40 \%$ & $37 \%$ \\
\hline Family Health & $06 \%$ & $07 \%$ & $11 \%$ & $40 \%$ & $38 \%$ \\
\hline \multicolumn{6}{|c|}{ Contribution of Livestock Income to Socio-economic Indicators Rank Wise } \\
\hline & \multicolumn{3}{|c|}{ Mean + SD } & \multicolumn{2}{|l|}{ Ranks } \\
\hline Food safety & \multicolumn{3}{|c|}{$3.11+0.036$} & \multicolumn{2}{|c|}{1} \\
\hline Households income & \multicolumn{3}{|c|}{$3.20+0.050$} & \multicolumn{2}{|c|}{2} \\
\hline Women Empowerment & \multicolumn{3}{|c|}{$3.082+0.032$} & \multicolumn{2}{|c|}{3} \\
\hline Education of the children & \multicolumn{3}{|c|}{$3.02+0.021$} & \multicolumn{2}{|c|}{4} \\
\hline Health of the households & \multicolumn{3}{|c|}{$3.01+0.061$} & \multicolumn{2}{|c|}{5} \\
\hline
\end{tabular}

Whereas: Socio-economic aspects (SEA), Strongly disagree (SD), Strongly Agree (SA). Moreover, percentages are in the parenthesis.

In this case, the table 06 contains the information related: food safety, family current income, health and education, the households raked them as first, second third and fourth respectively. Moreover, to improve the lives of people and provide them food security it is inevitable that the government should endorse livestock in the area.

\section{Conclusion and Recommendations}

The study tinted that the livestock contributes in food security of JelMagsi. There is no doubt that livestock do provide opportunities to society for economic development. Hence as majority of the population; and the socioeconomic status of farmers continue to be well expressed owing to livestock involvement. Furthermore, for the mainstream farmers livestock is one of the chief sources of current and permanent income to support livelihood 
and other provisions of life in countryside of Balochistan. Henceforth, majority of livestock income is castoff for education, health and for further food necessities, etc. Nevertheless that livestock delivers food security to a large chunk of population in Jal Magsi. Notwithstanding the strong contribution of livestock, the socio-economic situations of the farmers in Jal Magsiare still deprived and living under extreme poverty as they can't afford advanced technologies and other prerequisites of cultivation. Accordingly, it is need of the hours to enlarge the flexibility, convenience and organization services of the agriculturalists such as artificial insemination and additional indispensable, advance technologies.

\section{Reference}

Ali, J. (2007). Livestock sector development and implications for rural poverty alleviation in India. Livestock Research for Rural Development, 19(2), 1-15.

Freeman, H. A., Kaitibie, S., Moyo, S., \& Perry, B. D. (2008). Designing livestock interventions for emergency situations in Southern Africa.

Khan, K., Khan, G., Zahri, M., \& Altaf, M. (2015). Role of Livestock in Poverty Reduction: A Case Study of District Lasbela, Balochistan. Lasbela, UJ Sci. Techl, 153-156.

Khalil, J. K. (2007). Food security with special reference to Pakistan. Higher Education Commission.

Khan, K., Kamal, M. A., Zhao, H., Ullah, A., \& Saeed, F. Nexus Between livestock Ownership and Food Security: A Case Study of District Lasbela, Balochistan.

Khan, K., Kamal, M. A., Ramazan, S., Khan, G., Ali, G., \& Ahmed, S. (2018). Impact of Agricultural Credit on Livestock Income: A Case Study of District Lasbela, Balochistan. Sarhad Journal of Agriculture, 34(2).

Memon, M. H., Khan, K., Abbass, M. Y., Khan, G., \& Kamal, M. A. (2015). Impediments to Technology Adoption: A Case Study of Peach Production in District Swat, Pakistan. Journal of Managerial Sciences, $9(2)$.

Rigg, J., Bebbington, A., Gough, K. V., Bryceson, D. F., Agergaard, J., Fold, N., \&Tacoli, C. (2009). The World Development Report 2009 'reshapes economic geography': geographical reflections. Transactions of the Institute of British Geographers, 34(2), 128-136.

Shaikh, S. A., Hongbing, O., Khan, K., \& Ahmed, M. (2016). Determinants of Rice Productivity: An Analysis of Jaffarabad District-Balochistan (Pakistan). European Scientific Journal, ESJ, 12(13). 